\title{
BPJS Barrier to Strategic Purchasing of Primary Care Service at Public and Private Health Facilities in Subulussalam, Aceh
}

\author{
Satria Darma1), Juanita'), R. Kintoko Rochadi²) \\ 1)Department of Health Policy and Administration, Universitas Sumatera Utara \\ 2)Department of Health Promotion and Behavior Sciences, Universitas Sumatera Utara
}

\begin{abstract}
Background: Strategic purchasing plays an important role in the cost structure and competitiveness of small and large businesses. Managing Board of Social Insu-rance (BPJS) has implemented strategic purchasing of health services in the National Health Insurance (JKN) scheme. Strategic purchasing is important to provide quality products and services at low costs. Strategic purchasing of health service has five critical criteria: (1) what is to purchase; (2) to whom it is for; (3) whom it is from; (4) what is the price; (5) how to purchase it. This study aimed to assess BPJS barrier to strategic purchasing of primary care service at public and private health facilities in Subulussalam, Aceh.

Subjects and Method: This was a qualitative study conducted in Subulussalam, Aceh, from February to July 2015. A total of 12 key informants for this study, including BPJS administrators and hospital managers. The theme was strategic purchasing of health service. The data were collected by in-depth interview, direct observation, and document review. The data was analyzed by thematic analysis.

Results: BPJS administered the same standards of strategic purchasing health service from the public and private health providers. However, there were some unresolved problems: (1) BPJS faced difficulty to select primary care providers independently; (2) Illegal use of other member's JKN card to get health service; (3) Redundant claims from the primary care providers; (4) Claim of inpatient days exceeding the maximum allowable limit; (5) Delay in non-capitations reimbursement payment to primary care provider; (6) Inequitable distribution of health manpower across health facilities.

Conclusion: BPJS has implemented strategic purchasing of primary care services with the same standards applied to public and private primary care providers. However, there remain some problems of purchasing health services that call for immediate corrective actions, including routine monitoring, explanation of delay, advocacy, equitable distribution of health manpower.
\end{abstract}

Keywords: strategic purchasing, primary care service, health facility, BPJS.

\section{Correspondence:}

Satria Darma. Department of Health Policy and Administration, Universitas Sumatera Utara, North Sumatera. Email: s4tria.darma@yahoo.com. Mobile: 085260077824.

\section{BACKGROUND}

Health is a human right and one of the elements of prosperity that must be realized in accordance with the ideals of the Indonesian people. As referred to in Pancasila and the 1945 Constitution of the Republic of Indonesia, it is stated that every activity is done in an effort to maintain and improve the highest level of public health. This activity is carried out based on the principle of non-discriminatory, participatory, and sustainable in the framework of the formation of Indonesian human resources, as well as increasing the resilience and competitiveness of the nation for national development.

Since Indonesia reformed its health financing system by implementing a national health insurance program, there are still many problems faced in achieving universal 
health coverage, including problems with funding sources (revenue collection), pooling, quality control of health services (credensialing), participant satisfaction, access to health services which are still not evenly distributed and controls on health costs that have not been maximized encourage efficiency, as well as indications of fraud practices (Center for Financing Policy and Health Insurance Management, 2016).

Strategic purchasing in implementing health services has five criteria of important things which consist of: what to buy, for whom to buy, from whom to buy, how much to buy, and how to buy it. Every purchase that answers these five questions can be strategic (Djavad Ghoddoosi-Nejad, 2017). The strategic purchasing objective for BJPS is to identify the implementation of health services that must be purchased while considering cost effectiveness, choosing service providers, considering quality services, equitable human resources and determining how effective and efficient health services (KKI, 2017).

According to Elqorni (2009), strategic purchasing follows the principle agent theory system. The main principle of agency theory (agent theory) is the existence of a working relationship between the parties who give authority (principal), namely the owner or shareholder with the party receiving the authority (agent), namely the manager, in the form of a cooperation contract. Agency relationship is a relationship where the owner of the company (principal) entrusts the management of the company to others, namely the manager (agent) in accordance with the interests of the owner (principal) by delegating some decision-making authority to the manager (agent). Managers in running the company have an obligation to manage the company as mandated by the owner, namely to increase the principal's prosperity through increasing the value of the company, in return for the manager (agent) will get a salary, bonus or other compensation. An agency contains a system of mutual benefits between the principal and the agent so that the cooperation produces satisfaction for both.

In strategic purchasing, there are various principal-agent relationship frameworks that can be used to define the relationship between: buyers with providers, governments with buyers, and the community with buyers (Honda, 2016). The implementation of BPJS cooperation with health facilities is carefully crafted so that the benefits are beneficial for the parties by prioritizing the quality of strategic purchasing-based health services. Strategic purchasing is the process of planning, implementing, evaluating and controlling strategic and purchasing decisions to direct all purchasing function activities towards opportunities that are consistent with the company's ability to achieve long-term goals with mutual benefits. Strategic purchasing can build relationships with providers (government) to collectively draw costs from products or services provided by health facilities (Apostolova, 2015).

Health insurance in Indonesia is in the form of National Health Insurance (JKN) using a fund collection system using a single pool (single fund collection). The poor are financially supported by publicly funded premiums. JKN financing comes from the central government budget and some local government budgets, contributions from workers 'and companies' salaries, and premiums from community members. BPJS does not have a handle in the form of accreditation, negotiation, contract management and monitoring to ensure the quality of health care providers. There is a need to provide health services at 
the primary level using measures such as accreditation for basic services. The capacity and authority of BPJS to monitor the quality of health services is still limited, especially in relation to health facilities. JKN was implemented starting in 2014 and currently has guaranteed $52.9 \%$ of the total population (Ministry of National Development Planning, 2015).

The principal-agent relationship between purchaser (BPJS) and health facilities or providers aims to improve the quality of health services for the community having the ideal concept of selecting accredited Health Care Providers (PPK), making cost effective service contracts, developing drug formularies and clinical service standards, determine the amount of payment, guarantee accurate information and monitor PPK performance (Figueras, et al, 2005).

BPJS also applies sanctions to providers that have poor performance, audit provider claims, preventing and detecting fraud and corruption, paying providers on time, allocating resources to ensure justice for remote areas, implementing various strategies to encourage equitable access, monitoring implementation KDP payment policy, as well as developing and using information technology system information (Figueras, et al, 2005).

The principal-agent relationship between purchaser applies as an agent for the government (principal). The government must play a role in ensuring that priorities in public health are linked to the allocation of resources and decisions in the purchase of health services. In the context of purchasing, the government has three stewardship duties, including; formulating policies to determine the contents and direction of the health system; providing influence including approaches to regulation in the health sector, and 3) collecting and using intelligence to monitor health system performance (Figueras, et al, 2005).

Information obtained through indepth interviews revealed the number of government First Level Health Facilities (FKTP) in Subulussalam City amounting to 5 health facilities namely Penanggalan Health Center, Simpang Kiri Health Center, Runding Health Center, Longkib Health Center and Daulat Health Center.

The results of interviews with BPJS officers, FKTP and the community can be identified as follows: the uneven distribution of Health Human Resources is due to a shortage of health personnel, especially doctors and dentists in FKTP that are far from urban areas. The distribution of health personnel from Simpang Kiri Health Center was 6 people consisting of 4 general practitioners and 2 dentists serving 27,407 participants (paid with the highest tariff of $\mathrm{Rp}$ 6,00o/ capitation), 5 Community Health Centers consisting of 3 general practitioners and 2 dentists serving 15,241 participants (paid at the highest tariff of Rp 6,00o/ capitation), Sultan Daulat 2 center general practitioners served 17,043 participants (paid at a rate of Rp. 5,500 for having 2 doctors but not having a dentist), and the Runding Health Center 1 doctor. The general public served 13,935 participants (paid at a rate of Rp. 4,500 for not having a dentist), and Longkib center, 1 person served 6,312 participants (paid at a rate of Rp 4,500 for not having a dentist). Dissemination of health personnel that are not evenly distributed can cause differences in the quality of health services.

The number of types of diseases that must be serviced at the first service facility create an never-ending gap in improving the quality of health services in the region. Based on clinical practice guidelines for doctors at the first level health care facility, which initially lists 144 types of diseases 
that must be treated in primary services, it is transformed into 126 types of diseases. This is due to the limitation of health human resources spread in each FKTP and supporting facilities such as medical devices.

Payment of non-capitation funds that are always late in the process of payment by BPJS to FKTP causes the contract agreement between BPJS and FKTP not to proceed according to the applicable regulations. The existence of a drug vacuum in FKTP has an impact on the health service process. This is due to the Subulussalam Health Service's evaluation and monitoring of the Health Service has not been effective. Monitoring is not carried out periodically, especially for puskesmas that are far from the city center.

The occurrence of fraud indications include the use of BPJS cards that do not match the actual identity of the participants by borrowing other BPJS cards to deliver, double claim cases between FKTP, claiming the number of days of hospitalization at the Inpatient Health Center which exceeds the provisions causing the claim fees not to be paid by BPJS.

Public perception of health services in accordance with the strategic purchasing principle is very simple, namely, when getting health services in the form of treatment and care. The community is better looking at the free service and getting good service from health personnel then recovering, so they tend to feel satisfied with the situation.

The quality of health services provided by FKTP as a service provider is very important, considering that FKTP is the spearhead in providing health services, as well as the gatekeeper of health services. If the quality of FKTP is not improved, the referral rate will continue to increase so that there can be accumulation of patients in the hospital. FKTP as the first line of health services must be strengthened and continue to be committed to continue to provide optimal services. This is also an effort to control quality and costs in health facilities, as well as a real commitment from stakeholders to provide better quality services. Therefore, FKTP service quality indicators are needed so that FKTP who achieve service quality indicator standards will get maximum capitation (BPJS Health, 2017).

Research on strategic purchasing of health services is generally still in the form of passive purchasing or just to administer payment administration. The BPJS as a passive buyer or BPJS has not actively purchased the health service from the first level health services, either government health centers or private clinics or medical centers, whereas the funds provided are quite large so the importance of this research is to increase information and the quality of health services. Based on the above problems, the researchers are interested in reviewing BPJS purchasing strategic with FKTP in providing health services in the city of Subulussalam.

The problem that will be discussed in this research is about the obstacles faced by BPJS in implementing strategic purchasing in the first level of government health facilities. Furthermore, how the BPJS implements contract mechanisms, payment mechanisms and quality control mechanisms and costs and how BPJS buys health services from health facilities.

\footnotetext{
SUBJECTS AND METHOD

This was a descriptive study with a phenomenological approach. The research will be conducted at FKTP Subulussalam Municipality, from February to July 2018. Informants were determined purposively based on the consideration that they are consi-
} 
dered able to provide data and strategic purchasing information in health services at FKTP Subulussalam Municipality. Data collection in this study was conducted to obtain primary and secondary data through documentation and interview data collection techniques. To facilitate data processing and discussion, the definition of the research concept is formulated as follows.

1. Strategic puchasing is an effort to make changes in the public health financing system adhering to the principal-agent relationship system which has five important criteria, namely what must be purchased? Who is it for? Who should be bought from? What is the price? And how to buy it?

2. Providers are health care facilities at the first level as providers of health services to the community, including health centers, clinics and private doctor practices.

3. Purchaser is the one that organizes a national health insurance program as a buyer of health facilities from service providers according to the contract that has been set.

4. Government is a stakeholder who has a role as a stewardship in formulating health policies to establish the vision and direction of the development of the health system, implementing regulations and monitoring the performance of health systems.

5. Citizens are people as recipients of health services who have the responsibility to pay dues and receive dues every month.

In general, the process of analyzing qualitative data is based on the reduction and interpretation of data. In accordance with the theory of Cresswell (2012), the data analysis was carried out with the following stages.

\section{Data Reduction}

It consists of collecting and simplifying the information, choosing the main things and focusing on important things, looking for themes or patterns from reports or data obtained in the field. Thus the data that has been reduced will give a sharper picture of the results of the observation, in addition to making it easier for researchers to find the data needed.

\section{Display}

Presenting various information from the data after being analyzed in order to provide a complete picture or certain parts of the research conducted.

\section{Drawing onclusions and verifying the data}

Data analysis activities are intended to find meanings and make conclusions from the data that have been collected by looking for patterns, themes, relationships, similarities, things that often arise and working hypotheses.

RESULTS
The results of the study were obtained
based on the results of interviews and docu-
mentation qualitatively which were divided
into three interview groups, namely, pro-
viders, communities and government.
Based on the BPJS statement, the government still cooperates through a good credentialing process, but the provider will choose a provider that is considered suitable for the cooperation. For further information, BPJS states that the Health Service can review the contents of the SPK, the Health Service can also provide feedback to the BPJS, such as non-capitation funds and these funds are not paid monthly. In the implementation, there was a delay in payment because it had to go through the verification stage, for example, it was received in April, but it was paid in May. Addressing the problem of delay, currently 
Journal of Health Polic and Management (2018), 3(2): 81-91

https://doi.org/10.26911/thejhpm.2018.03.02.03

the non-capitation claim document verified by the Health Office is then submitted to the BPJS.

The information received by BPJS on services by FKTP (primary care service) was information on the number of referrals and visits each month that were inputted through the P-Care application. To develop drug formularies and clinical service standards, the BPJS conducted the observation in the field. If there was a lack of drugs, it would be conveyed to the Health Office, such as the unavailability of TB medicine at the Sultan Daulat Public Health Center, therefore, it was reported to the Health Service. Related to the determination of the amount of payment to FKTP, it would also be adjusted to the derivative rules that referred to the provisions of the Minister of Health Regulation of RI.

The monitoring of health care provider (HCP) performance and the application of sanctions for poor performance were carried out by BPJS in every period. In addition, BPJS also has a WA group with the FKTP. However, for remote FKTP, monitoring was rarely done directly. The Community Health Center (CHC) which were considered to perform well were accredited CHC, namely Penanggalan, Simpang Kiri and Runding CHC. However, the Runding Health Center has some problems due to internal problems.

Fraud and corruption prevention was done by verifying each part either by the system or directly. Through "by system", a lot of fraud was found, but there were only few fraud in the field which were used as samples. In the working area of the Runding Community Health Center, it was done by visiting the houses of the residents, for example, a daughter from a family gave birth to a child in the Village Health Pos, but the BPJS card which was used for the birth process was on behalf of the mother.
As a result, the claim submitted was not paid. Health center that has a lot of fraud was the health center that claim the most, which was Sultan Daulat health center. The data found were related to inpatient data, non-capitation claims such as ambulance and labor referral fees.

Payments to the providers were done for capitation and non capitation funds. For the capitation fund, BPJS admitted that they had never made late payments. This was because the limit date for capitation funds payment was on the 4th of each month. However, the delays were often experienced by non capitation funds. This delay was due to the non-capitation fund payment which had to go through the file verification process first.

The results of the interview found that FKTP was in accordance with the minimum HR requirements in the Penanggalan and Simpang Kiri health centers. Therefore, these two $\mathrm{CHC}$ have the right to get a capitation fee which multiplied by $\mathrm{Rp} 6000$, while 3 other health centers only paid for Rp 4,500. These three health centers were not in accordance with the proportion of doctors. Ideally, 5000 residents were covered by at least one doctor. Until now, the lack of human resources has been communicated with the Health Office, but there have been no additional doctors in the three health centers. The monthly Utilization Review was expected to provide input and evaluation material to encourage equitable access to health services, especially for remote areas. Through the system created by BPJS on the www.hfis.bpjs/kesehatan.go.id website, it was expected that this website can help to support the completeness of the information needed. However, existing health facilities must support by updating the data every quarter on the system. 
Related to the service needs and preferences from the community, it stated that the BPJS monitored the community toward the fulfillment of health services called Walk True Audit. To guarantee the fulfillment and use of special services or special benefits, BPJS stated that FKTP did not exist yet, but in the BPJS office, there was a special seat for pregnant women and the elderly, and they were prioritized in the queue process.

The BPJS conducted socialization once a week per village to ensure that the community knew their rights and obligations. The steps of the BPJS to ensure that the public can access the services needed were by monitoring through the calculation of the KBK per FKTP, reward, and punishment in the Capitation-Based Services Commitment (maximum capitation cuts of 2.5 percent). An effective mechanism for a clear complaints handling and feedback to the community according to BPJS was through the direct complaints by the community. Published reports on various BPJS performance and the use of accountability resource can be found in national newspapers each year.

Special Local Government policies which implemented for good relations between BPJS and HCP through the Utilization Review were conducted every month (meetings with FKTP and Health Service). The review was related to the number of visits, number of referrals, information about the lack of HR and Stakeholder Forums. This forum involved the Regional Secretary, Civil Registry Service Office, Local Development Planning Agency, Head of Social Services, Health Office, Hospital Director, and Manpower Services.

The infrastructure of Local Government has evenly distributed, but the location of the Longkib Health Center was less strategic. Community Health Centers and medical devices which used operationally were sufficient but the number of patient visits was still lacking due to the distance of the community's residence which was quite far. In other words, the health centers were not in a strategic place. The other obstacle was that the local government has not distributed the human resources in every FKTP.

\section{DISCUSSIONS}

The discussion was conducted to analyze the issues related to the research objectives, namely to analyze the health services purchased by BPJS to the primary level of public health facilities, analyze the implementation of contract mechanisms, payment mechanisms, costs and quality control mechanisms, and to analyze the purchase of health services from health facilities.

Based on the results of the study, it was found that the monitoring of HCP performance was done by doing direct checking to the related FKTP and forming a social media group by using the Whats App (WA) application. Health centers that were considered to have good performance were the Penanggalan, Simpang Kiri, and Runding community health centers, although it was known that currently the Runding health center has internal problems. However, for the other two Community Health Centers, Longkib and Sultan Dulat Health Centers were still considered to have poor performance.

The step taken by BPJS to improve the performance of Community Health Centers and prevent fraud or corruption was by conducting the system verification directly. The verification results indicated that there were still many frauds or corruption, especially at the Sultan Daulat Health Center. The obstacle that occurs was that the direct verification was rarely done due to a long distance. Therefore, the direct 
Journal of Health Polic and Management (2018), 3(2): 81-91

https://doi.org/10.26911/thejhpm.2018.03.02.03

monitoring activity should be increased to reduce the possibility of fraud or corruption in the health centers.

A study done by Budiarto (2015) found that there was an effect given by the distance variable on the FKTP preference in Banda Sakti Subdistrict, Lhokseumawe City. Therefore, it was recommended to the public FKTP in Banda Sakti Subdistrict, Lhokseumawe City to conduct mobile health services in each village on a regular basis so that the community with a great distance from the public FKTP can access the health services. Public FKTP must also improve the quality of services through improving the reliability of health personnel, physical evidence of good health facilities, good responsiveness by health personnel, guarantee of health services, and optimal attention provided by health personnel.

The above steps can be used as an alternative consideration to improve health services provided by FKTP to the community. Along with the implementation of these steps, the BPJS must also improve monitoring activities for all existing FKTP. By increasing monitoring and mobile health services, it would optimize the performance of FKTP and reduce the possibility of fraud or corruption.

The next phenomenon found from the results of this study was related to provider payments that were not in time, especially for non-capitation funds. Non-capitation funds often experienced delays. This delay was due to the non-capitation fund payment which have to go through the file verification process first.

The effort made by BPJS for the distribution of human resources in each FKTP was by submitting a proposal to the Health Office. However, there has been no additional human resources for the three proposed health centers, namely the
Runding, Longkib, and Sultan Daulat community health centers. A study by Wasis (2001) showed that District/City Health Office policies and strategies in supporting health center reformations that have been done by HR field were the effort to equalize health personnel with employment contracts, health efforts were conducted through the enhancement of health services access by means and revitalization of Community Health Center, the health financing sector was done through selfreliance of health center with the autonomy of financing as well as increasing APBD financing support for health, and the field of health management was done by clarifying the division of authority between provinces, regencies/cities, independence of health center, health centers services with ISO 9001 certification, and revitalization of HRHE.

Reform of health human resources was done through equalizing the health personnel with employment contracts, because the ratio of population health personnel was very varied. The utilization has not been fully supported by the provision of other adequate resources (financing, facilities and infrastructure, and logistics). The regions needed to plan the needs of health resources (human resources, facilities, medicines, and medical supplies) and cooperation between the regions, especially those which related to training and facilitation of health in the area. Thus, it was expected that all deficiencies in the field, especially those which were related to the lack of human resources could be overcome as soon as possible.

The occurrence of fraud in this study can be found in every FKTP in the city of Subulussalam. Based on the results of indepth interviews conducted, frauds that were found were among others: 
1. The ratio of midwife claims to 5 - 10 pregnant women per month, it was found that there was a midwife who has filed a claim for delivery costs to another midwife. However, after doing an observation, there was no appropriate data.

2. Using other people's NHI cards in the labor claim process. After checking the system, the wife and husband's name was not appropriate.

3. Faking the date of birth, for example a mother gave birth in 2016, but it was not claimed by the officer, then the claim was increased in 2017.

4. A mother has a 12 years old child as the youngest one, then a new labor claim was submitted to the BPJS. After being traced, it turned out that the claim was fictitious.

5. A mother gave birth cesareanly at the hospital, and it was claimed at FKTP.

6. Ambulance transport costs. People who have dispexia disease was asked to use an ambulance even though it was not an emergency.

7. Hospitalization was increased by the number of days. For example, 2 days of hospitalization were raised into 3 to 4 days.

8. There have been double claims between Penanggalan Health Center and Medika Clinic.

This can occur due to poor performance of existing human resources in each FKTP. The weaknesses of FKTP according to BPJS were:

1. Many participants were asked to move by FKTP officers when participants asked for pulmonary tuberculosis medication, immunization, while in fact it was a government program, even though the FKTP data was different, but it had to be given or served.
2. Prioritizing administrative completeness in advance, new actions/services were carried out to the patient. However, the administrative completeness can be ignored and it can be done after the treatment. For example, if the participant's card was not active, it must be reported to the BPJS first.

3. There was a patient who asked for referral to the hospital to check her pregnancy through USG but the officers at FKTP did not give permission because there was no medical diagnosis. While in fact it was permitted. Participants have rights to get 3 ultrasound checks, starting from trismester I to trismester III. In fact, this explanation has often been done to FKTP. The second example was cholesterol, sugar, and uric acid check up should be included in the capitation so it did not have to be charged. Participants should get the right of getting the check up once in a month.

4. P-care input was not in time.

5. A less friendly attitude from FKTP officers.

6. The Head of the Longkib Health Center ignored the administration (reporting), even though he had been given a oneweek deadline, but the administration was still ignored for a month.

7. Runding Health Center has a problem in terms of non capitation.

8. The doctors who were supposed to be on duty often ignored their obligation.

But despite the weaknesses found above, there were still advantages that the FKTP has to maintain in doing the services, including:

1. Citations Traffic Accident Cost in FKTP Sultan Daulat did not happen anymore, since 1 April 2018, the traffic incident has been borne by BPJS.

2. The doctors came to work more often. 
3. Good service was done at the Penanggalan health center, they prioritized the services than administration problems.

4. Of the 5 Puskesmas that have collaborated with BPJS, the Penanggalan health center was a benchmark of service at the Subulussalam FKTP.

Based on the results and discussion, the conclusion of this study was the implementation of monitoring by BPJS to FKTP still need to be improved. The service performance provided by FKTP was still considered to be poor, so there was still a need for supervision and various improvements to the existing system. It was recommended to FKTP in Subulussalam City to conduct mobile health services in each village on a regular basis so that people with a great distance from public FKTP can access health services. The distribution of human resources in the city of Subulussalam was not good. This was evidenced by the discovery of three Community Health Center, namely the Runding, Longkib, and Sultan Daulat Health Center which experienced a lack of human resources in conducting operational activities. This lead to lack of strategic purchasing implementation so that the BPJS was still a passive purchasing in terms of cooperation with FKTP.

It was expected that the FKTP in Subulussalam Municipality could conduct mobile health services in each village on a regular basis so that people with a great distance from the public FKTP can access the health services. The regions were expected to be able to plan the needs of health resources (human resources, means, facilities, medicines, and medical supplies) and conduct inter-regional cooperation, especially those which were related to training and health facilitation in the area. Furthermore, socialization to citizens has to be improved, this was useful to provide understanding and knowledge to the public about their rights and obligations in using health services at the FKTP.

\section{REFERENCES}

Al-Saa'da RJ (2013). Supply Chain Management and Its Effect on Health Care Service Quality: Quantitative Evidence from Jordanian Private Hospitals. Journal of Management and Strategy. 4(2): 42-51.

Apostolova BZ, Kroon MJ, Richter M, Zimmer IM (2015). Strategic Purchasing: A Global Perspective. University of Groningen:.

BPJS Kesehatan (2017). Pelaksanaan Kapitasi Berbasis Komitmen Pelayanan Disempurnakan. Siaran Pers. Diperoleh dari: https://bpjs-kesehatan. go.id/bpjs/dmdocuments/27ec136c73 d37bef37473474bcc1c94e.pdf

Budiarto, Kristiana (2015). Pemanfaatan Dana Kapitasi Oleh Fasilitas Kesehatan Tingkat Pertama (FKTP) Dalam Penyelenggaraan JKN. Surabaya: Kementerian Kesehatan.

Creswell JW (2012). Research design Pendekatan kualitatif, Kuantitatif dan. Mixed; Cetakan ke-2, Yogyakarta: Pustaka Pelajar.

Elqorni A. Mengenal Teori Keagenan, Diperoleh dari: http://elqorni.Wordpress.com.

Figueras $\mathrm{J}$, Robinson $\mathrm{R}$, Jakubowski $\mathrm{E}$ (2005). Purchasing to improve health systems performance. Cambridge: Open University Press.

Ghoddoosi-Nejad D, Janati A, Zozani MA (2017). Is strategic purchasing the right strategy to improve a health system's performance? A systematic review. Bali Medical Journal. Bali Med J. 6(1): 102-113. 
Hasibuan, Malayu SP (2009). Manajemen: Dasar, Pengertian, dan Masalah. Edisi Revisi. Jakarta.

Hendrartini Y (2017). Strategic Purchasing Dalam Implementasi JKN. Magister Kebijakan Pembiayaan dan Manajemen Asuransi Kesehatan. Yogyakarta: Universitas Gadjah Mada.

Honda A, Di McIntrye, Hanson K (2016). Strategic Purchasing in China, Indonesia and the Philippines. Comparative Country Studies. 2(1).

Kebijakan Kesehatan Indonesia (2017). Pengantar Blended Learning: Peningkatan Kemampuan Penggunaan Strategic Purchasing dalam Kebijakan JKN. Diperoleh dari: http://kebijakankesehatanindonesia.net/40-strategic-purchasing.

Kemenkes RI (2011). Undang-Undang Nomor 24 tahun 2011 tentang Badan Penyelenggara Jaminan Sosial (BPJS). Jakarta.

(2014). Undang-Undang No. 40 Tahun 2014 tentang Sistem Jaminan Sosial Nasional (SJSN). Jakarta.

(2017). Buku Pegangan Sosialisasi Jaminan Kesehatan Nasional (JKN) dalam Sistem Jaminan Sosial Nasional. Pusat Pembiayaan dan Jaminan Kesehatan Kementerian Kesehatan R.I. Jakarta.

Kementerian Perencanaan Pembangunan Nasional (2015). Satu Tahun Pelaksanaan JKN. Jakarta.

Kumorotomo W, Margono AS (2011). Sistem Informasi Manajemen Dalam Organisasi-Organisasi Publik: Gadjah. Mada University Press.

Manullang (2008). Dasar-Dasar Manajemen, Yogyakarta: Ghalia Indonesia.

Mcnamara P (2006). Purchaser strategies to influence quality of care: from rhetoric to global applications. Qual Saf Health Care. 15(3): 171-173.
Moleong LJ (2011). Metodologi Penelitian Kualitatif Edisi Revisi. Bandung: PT. Remaja Rosdakarya.

Mulyadi (2007). Sistem Perencanaan dan Pengendalian Manajemen. Jakarta: Salemba. Empat.

Pemerintah Kota Subulussalam (2017). Subulussalam Dalam Angka. Badan Pusat Statistik Kota Subulussalam.

Pillay R (2015). Value of Contracting as a Strategic Purchasing Mechanism in a Private Health System: A South African Case Study. Master in Public Health (Health Economics) Faculty of Health Science University of Cape Town.

Pusat Kebijakan Pembiyaan dan Manajemen Asuransi Kesehatan (PKMK), 2016. Diskusi Umum Strategic Purchasing. Diperleh dari: http://id.kpmak-ugm.org/diskusi-umum-strategic-Purchasing.

Pusat Kebijakan dan Manajemen Kesehatan (PKMK), 2017. Seminar Nasional: Pelaksanaan Konsep Stewardship Dalam Jaminan Kesehatan Nasional. Yogyakarta: Pusat Kebijakan dan Manajemen Kesehatan (PKMK) FK UGM bekerjasama dengan Badan Pelaksana Jaminanan Sosial (BPJS) Kesehatan. Diperoleh dari: https://www.mutupelayanankesehatan.net/14 -agenda/2669-pelaksanaan-konsepstewardship-dalam-jaminan-kesehatan-nasional.

Solihin I (2009). Pengantar Manajemen. Jakarta: Erlangga.

Thabrany H (2015). Jaminan Kesehatan Nasional. Edisi Kedua. Jakarta: PT RajaGrafindo Persada.

Wasis B, Tety R, Ristiani (2011). Kebijakan Dan Strategi Dinas Kesehatan Kabupaten/Kotadalam Endukung Reformasi Di 6 Provinsi Di Indonesia. Surabaya: Kementerian Kesehatan 